\title{
The Phosphate Content of Sea Water in relation to the Growth of the Algal Plankton. Part III.
}

\author{
By \\ W. R. G. Atkins, Sc.D., F.R.S., \\ Head of the Department of General Physiology at the Plymouth Laboratory.
}

With 5 Figures in thə Text.

The first two papers of this series, which appeared under slightly different titles $(1923,1925)$, showed that there is a seasonal change in the phosphate content of the surface water of the English Channel, thus confirming the work of Matthews, who found that in spring and summer almost all the phosphate was used up, presumably by plants. It was further shown that such changes were experienced by the deeper water also, so that when the surface water was at its minimum phosphate value the bottom water, 70 metres, at Station E1 was reduced to $11 \mathrm{mg}$. per cubic metre, less than a third of its winter and maximum value.

A comparison of the years 1923 and 1924 made it clear that the changes were qualitatively identical, and quantitatively very nearly so, differing only slightly in the maximum and minimum values, though more noticeably in the dates at which these values were reached.

Since all the phosphate is used up when and where the illumination is sufficient it appears to be the factor limiting further growth, so knowing approximately its concentration in the phytoplankton it is possible to make an estimate of the wet weight of vegetable matter produced. This is obviously a minimum value, for in its simplest form it neglects, in this estimate of the annual crop, the possibility of a portion of the phosphate being used twice over, or more often, through decay, or the consumption $\mathrm{cf}$ the plant cells by animals - the latter process being followed in time by excretion or decay.

Again, since the deeper the water the less is the light intensity, it seemed probable that water from the region of total darkness might be far richer in phosphate than that near the bottom in the comparatively shallow English Channel. This supposition was confirmed to some extent by the results recorded in Tables 11, 12 and 13 of Part II.

Furthermore, the bright light experienced even in winter in latitudes nearer the equator gives reason to suppose that under such conditions 
the seasonal changes in phosphate concentration will be less marked than they are here. Data confirming this view are given in Table 14 of Part II. There is another reason why the surface waters in warm latitudes should remain poor in phosphate, namely, the stability of the water owing to the marked temperature gradient, so that warm water is normally present at the surface. In our northerly latitudes, as the water surface cools in autumn, a stage is reached when the bottom water is the warmer. A condition of instability is thus produced and a very complete vertical mixing ensues, save in special cases where differences in salinity are sufficient to maintain the higher density at the bottom.

In the present paper data on the seasonal changes for 1925 are presented, and their onsets compared with those of the two preceding years. Owing to the assistance of scientific colleagues and others who so kindly provided the author with water samples, records of temperature and of position, it has also been possible to include analyses of water from a wide area of the Atlantic Ocean and the North Sea, including specimens from great depths, unobtainable hitherto, also some from the Pacific Ocean. These afford information concerning the seasonal changes, or their absence at different latitudes, and are of particular interest in permitting a conclusive test to be made as to the richness of deep ocean water.

It may be added that the depth series results for August 8th, 1924, in the Faroe-Shetland Channel, given in Part II, Table 12, has now been definitely proved to have been vitiated by the phosphate yielded by the white glass bottles; this was suspected at the time, and the bottles when tested later by storage gave up phosphate to distilled water. Fortunately, however, another series from near the same position became available this year, and the analyses are shown in Table 9. The green glass bottles in general use yield no phosphate.

Seasonal Changes in the Phosphate Content at L Stations, 1925.

Table 1 shows the changes in phosphate undergone by the surface water from L1, in the Sound in front of the Laboratory, past L5 (the Eddystone), right out to the International Hydrographic Station E1, twenty-two miles from L1. Similar data for 1923 and 1924 have been presented in Parts I, Table 5, and II, Table 1. This year, however, a series of bottom samples, from L4, three miles clear of the headlands, was also examined. The low summer values, denoting complete exhaustion of phosphate supplies, are clearly shown, the figures for August 31st being specially noteworthy, for it is seen that in spite of a considerable regeneration of phosphate early in the month, it has been very completely used up right down to the bottom; this change has taken place 
to an even greater extent than at the same depth at E1, for L4 being nearer the shore there is rather more vertical mixing of the water. This series is naturally somewhat irregular, owing to the presence of phosphate carried out by the river water. The irregularity is, however, far less than might be expected.

\section{TABLE 1.}

Surface Values for Phosphate as $\mathrm{P}_{2} \mathrm{O}_{5}$ IN Mg. Per M ${ }^{3}$ From Ll to E1, 1925, AND L4, 40 м.

\begin{tabular}{|c|c|c|c|c|c|c|c|c|c|c|c|c|c|}
\hline Station & $\begin{array}{l}\text { Jan. } \\
\text { 19th }\end{array}$ & $\begin{array}{l}\text { Feb. } \\
\text { 17th }\end{array}$ & $\begin{array}{l}\text { Mar. } \\
\text { 14th }\end{array}$ & $\begin{array}{l}\text { April } \\
22 \text { nd }\end{array}$ & $\begin{array}{l}\text { May } \\
13 \text { th }\end{array}$ & $\begin{array}{l}\text { June } \\
\text { 3rd }\end{array}$ & $\begin{array}{l}\text { July } \\
\text { 8th }\end{array}$ & $\begin{array}{l}\text { Aug. } \\
5 \text { th }\end{array}$ & $\begin{array}{l}\text { Aug. } \\
\text { 31st }\end{array}$ & $\begin{array}{l}\text { Oct. } \\
\text { lst }\end{array}$ & $\begin{array}{l}\text { Nov. } \\
\text { llth }\end{array}$ & $\begin{array}{l}\text { Dec. } \\
\text { l1th }\end{array}$ & $\begin{array}{l}\text { Jan. } \\
\text { 12th }\end{array}$ \\
\hline LI & - & 25 & 26 & - & 5 & 一 & 3 & 6 & - & - & - & 28 & 48 \\
\hline L2 & 39 & 41 & 28 & 2 & 0 & - & 2 & 6 & - & 28 & - & 27 & 43 \\
\hline L3 & 28 & - & 27 & - & 0 & 4 & - & 6 & - & 22 & 23 & 27 & 40 \\
\hline L4 & 28 & 33 & 38 & 3 & 1 & 2 & 3 & 7 & 1 & 15 & 18 & 25 & 40 \\
\hline L4 (40) & 32 & 29 & 46 & 26 & 5 & 19 & 6 & 23 & 2 & 20 & 24 & 24 & - \\
\hline L5 & 28 & 29 & 29 & 2 & 0 & 4 & 2 & 8 & 1 & 6 & 24 & 24 & 40 \\
\hline L6 & 30 & 31 & 14 & - & 0 & 4 & 3 & 2 & - & 7 & 26 & 19 & 40 \\
\hline \multirow[t]{2}{*}{ El } & 31 & 33 & 23 & 1 & 1 & 3 & 0 & 5 & 0 & 8 & 25 & 12 & - ${ }^{*}$ \\
\hline & Jan. & Feb. & Mar. & April & May & June & July & Aug. & Sept. & Oct. & Nov. & Dec. & Jan. \\
\hline Analysed & 21st & 20th & 17th & 23rd & 16th & 4th & 10 th & 6 th & 5 th & 2nd & 13th & 17 th & 12th \\
\hline
\end{tabular}

\section{Seasonal Changes in the Phosphate Content at Station E1.}

In Table 2 the data given in Parts I, Table 7, and II, Table 3, are continued. The results for the three years are shown in Fig. 1 for the surface water and in Fig. 2 for the bottom. The high values for $15 \mathrm{~m}$. on March 14 and $10 \mathrm{~m}$. on June 3 are evidently due to the inclusion of a particle rich in phosphate or to chance pollution of the water by fish, etc. Such instances have been noted previously. Special care was taken this year always to examine the samples when quite fresh, so that the high values shown for August 5 are undoubtedly due either to regeneration of phosphate at, or to the movement of water, richer in phosphate, to, E1. This confirms the apparent regeneration shown in August and September of the 1923 curve, though in these cases a delay of about ten days between the drawing of the sample and its analysis introduced some measure of doubt. Regeneration, a process which we must imagine to be continually active, becomes not:ceable only when the phosphate set free remains in a region poorly illuminated. Thus as may be seen in Table 2 and Fig. 3 there was a noticeable renewal of phosphate in the bottom water between May 13 and June 3. During this time, be it noted, the bottom water remained at $10 \cdot 0^{\circ}$, whereas the

* May safely be taken as 40 . 
surface water rose from $10 \cdot 7^{\circ}$ to $12 \cdot 6^{\circ}$; but by July 8 the bottom had risen to $11 \cdot 8^{\circ}$, denoting a considerable mixing with the warmer surface water, which by this time had risen to $16 \cdot 0^{\circ}$. Consequent upon the mixing the phosphate content fell to slightly under half its June value. Between

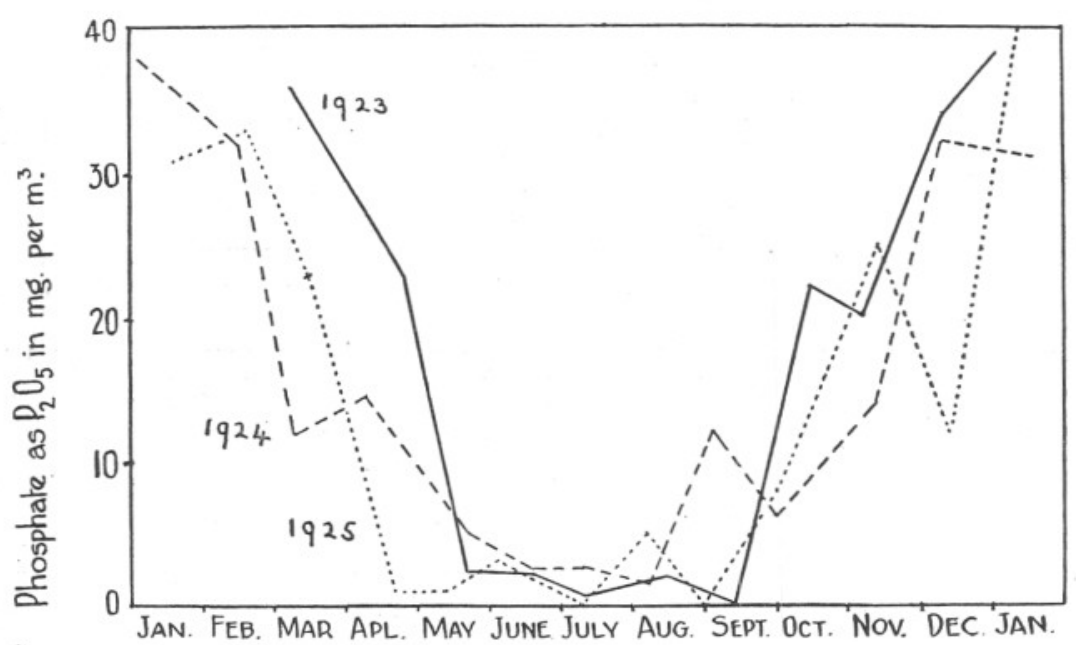

FIG. 1.-Seasonal changes in phosphate concentration at Station E1, surface.

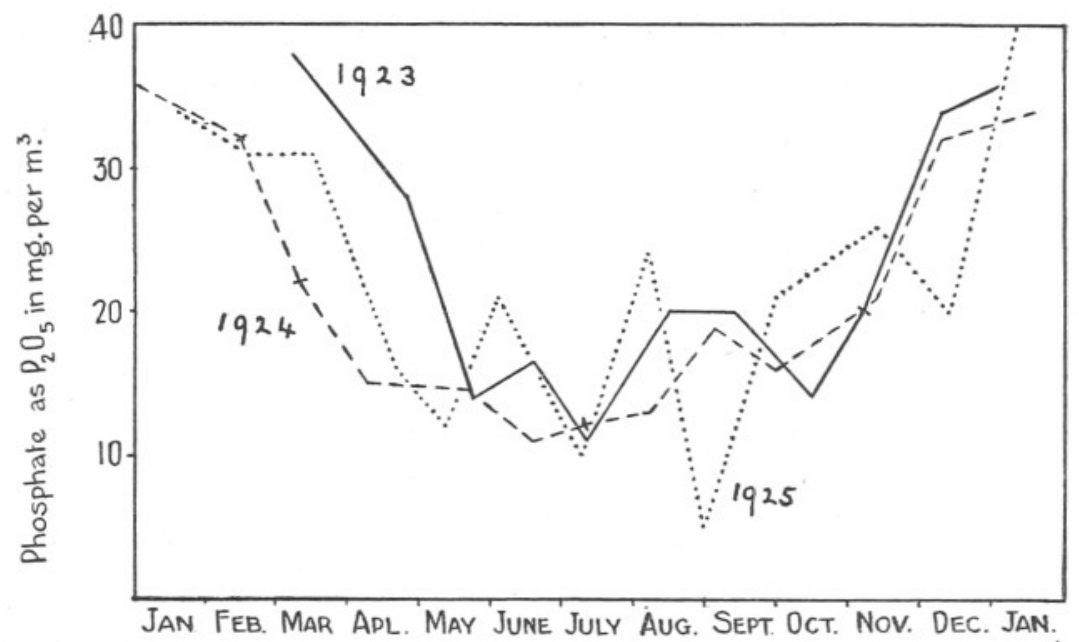

Frg. 2.- Seasonal changes in phosphate concentration at Station E1, bottom, 70 metres.

July 8 and August 5 the bottom only rose $0 \cdot 2^{\circ}$, and again the bottom water became enriched with phosphate. The August 31 series shows a gain of $0.8^{\circ}$ for the bottom, and a fall in phosphate to about one-fourth of its previous value. This stripping of the water, so that from $20-70 \mathrm{~m}$. 
it contained only $6 \mathrm{mg}$. per $\mathrm{m}^{3}$, has been more complete this year, 1925, than in either of the two previous years. Unfortunately it was not possible to obtain samples early in September to see whether the minimum had been reached, but October and November analyses showed the normal autumnal preponderance of regeneration.

For 1923 the average consumption at Station E1, surface to bottom, 70 metres, was $29 \cdot 6 \mathrm{mg}$. of $\mathrm{P}_{2} \mathrm{O}_{5}$ per $\mathrm{m}^{3}$, leaving a balance of $7 \cdot 4$ out of the original 37 mg., which, however, was a March value. For 1924

\section{TABLE 2.}

Values for Phosphate as $\mathrm{P}_{2} \mathrm{O}_{5}$ In Mg. Per $\mathrm{m}^{3}$ at Station E1, Surface to Bottom, During 1925, also Surface and Bottom TemperaTURES, THEIR DIFFERENCES AND THE DIFFERENCES BETWEEN SUCCessive Observations of Bottom Temperature.

\begin{tabular}{|c|c|c|c|c|c|c|c|c|c|c|c|c|c|}
\hline Depth & $\begin{array}{l}\text { Jan. } \\
\text { 19th }\end{array}$ & $\begin{array}{l}\text { Feb. } \\
17 \text { th }\end{array}$ & $\begin{array}{l}\text { Mar. } \\
14 \text { th }\end{array}$ & $\begin{array}{l}\text { April } \\
22 \text { nd }\end{array}$ & $\begin{array}{l}\text { May } \\
13 \text { th }\end{array}$ & $\begin{array}{c}\text { June } \\
\text { 3rd }\end{array}$ & $\begin{array}{l}\text { July } \\
\text { 8th }\end{array}$ & $\begin{array}{c}\text { Aug. } \\
\text { 5th }\end{array}$ & $\begin{array}{l}\text { Aug. } \\
\text { 31st }\end{array}$ & $\begin{array}{l}\text { Oct. } \\
\text { lst }\end{array}$ & $\begin{array}{l}\text { Nov. } \\
\text { llth }\end{array}$ & $\begin{array}{l}\text { Dec. } \\
\text { l1th }\end{array}$ & $\begin{array}{l}\text { Jan. } \\
12 \text { th }\end{array}$ \\
\hline 0 & 31 & 33 & 23 & 1 & 1 & 3 & 0 & 5 & 0 & 8 & 25 & 12 & $40^{*}$ \\
\hline 5 & - & 31 & 25 & 一 & 4 & 6 & 3 & $7 \cdot 5$ & 2 & 11 & 一 & - & - \\
\hline 10 & - & - & 28 & 3 & 5 & 104 & 5 & 7 & 2 & $11 \cdot 5$ & 26 & 19 & - \\
\hline 15 & 一 & 一 & 38 & - & 5 & 7 & 6 & 9 & 45 & 14 & - & - & 一 \\
\hline 20 & - & - & - & - & 7 & 12 & 5 & 16 & 6 & 17 & - & 19 & - \\
\hline 25 & 31 & - & 27 & 5 & 7 & - & 5 & 23 & - & 19 & 一 & - & - \\
\hline 30 & - & - & - & 一 & 11 & 17 & 7 & 24 & $6 \cdot 5$ & 19 & 26 & 19 & 一 \\
\hline 40 & - & - & - & - & 12 & - & 7 & - & $6 \cdot 5$ & 24 & - & - & - \\
\hline 50 & 32 & - & 30 & 13 & - & 21 & 9 & 一 & - & 20 & - & - & - \\
\hline 60 & - & - & - & - & - & - & 10 & - & - & 21 & - & - & - \\
\hline 70 & 34 & 31 & 31 & 16 & 12 & 21 & 10 & 24 & 5 & 21 & 26 & 20 & - \\
\hline & Jan. & Feb. & Mar. & April & May & June & July & Aug. & Sept. & Oct. & Nov. & Dec. & Jan: \\
\hline Analysed & 21st & 20th & 17th & $23 \mathrm{rd}$ & 16 th & 4th & 10 th & 6 th & 5 th & 2nd & 13th & 17th & 12th \\
\hline 0 & $10 \cdot 8^{\circ}$ & $9 \cdot 8^{\circ}$ & $9 \cdot 3^{\circ}$ & $9 \cdot 8^{\circ}$ & $10 \cdot 7^{\circ}$ & $12 \cdot 6^{\circ}$ & $16 \cdot 0^{\circ}$ & $15 \cdot 4^{\circ}$ & $16 \cdot 3^{\circ}$ & $14 \cdot 9^{\circ}$ & $11 \cdot 8^{\circ}$ & $10 \cdot 8^{\circ}$ & $9 \cdot 9^{\circ *}$ \\
\hline 70 & $10 \cdot 8^{\circ}$ & $10 \cdot 0^{\circ}$ & $9 \cdot 2^{\circ}$ & $9 \cdot 5^{\circ}$ & $10 \cdot 0^{\circ}$ & $10 \cdot 0^{\circ}$ & $11 \cdot 8^{\circ}$ & $12 \cdot 0^{\circ}$ & $12 \cdot 8^{\circ}$ & $13 \cdot 6^{\circ}$ & $13 \cdot 0^{\circ}$ & $11 \cdot 0^{\circ}$ & - \\
\hline$\Delta \mathrm{t}$ & $0 \cdot 0^{\circ}$ & $-0 \cdot 2^{\circ}$ & $0 \cdot 1^{\circ}$ & $0 \cdot 3^{\circ}$ & $0 \cdot 7^{\circ}$ & $2 \cdot 6^{\circ}$ & $4 \cdot 2^{\circ}$ & $3 \cdot 4^{\circ}$ & $3 \cdot 5^{\circ}$ & $1 \cdot 3^{\circ}$ & $-1 \cdot 2^{\circ}$ & $-9 \cdot 2^{\circ}$ & - \\
\hline$\Delta^{\prime} \mathrm{t}$ & - & $-0 \cdot 8$ & $-0 \cdot 8$ & $+0 \cdot 3$ & $0 \cdot 5$ & $0 \cdot 0$ & $1 \cdot 8$ & $0 \cdot 2$ & $0 \cdot 8$ & $0 \cdot 8$ & $-0 \cdot 6$ & $-2 \cdot 0$ & - \\
\hline
\end{tabular}

the corresponding figures were: used up, $28.3 \mathrm{mg}$.; balance unconsumed, 8.7 mg. ; winter concentration having again been $37 \mathrm{mg}$. For 1925 the maximum was probably missed; it occurred about January 2 in 1924, but no samples were available till January 19th this year. However, December 9th, 1924, gave $32 \mathrm{mg}$. and January 19th $31.9 \mathrm{mg}$.; accordingly taking 32 as the maximum, and the minimum value of August 31, namely, 5·1 mg., the amount used up was $26 \cdot 9 \mathrm{mg}$. per $\mathrm{m}^{3}$. These, however, are gross values. They take no account of the amounts

* In reality these are values for L6, but as L3-L6 gave same value for phosphate water was uniform and values may be taken for El. Weather tos bad to do depth series, water probably uniform to bottom. 
set free by regeneration and again utilized. Were this known accurately the total crop could be found with a correspondingly increased exactness. An attempt may be made to do this by finding out, for each year, the total consumption of phosphate, including what is ascertained to have been available owing to regeneration or replenishment by water which may have moved into the area studied.

Data showing the monthly loss, viz. utilization, of phosphate and the gain, viz. regeneration, for the whole water column, surface to bottom at Station E1 are shown in Table 3 and in Fig. 4 for the three years.

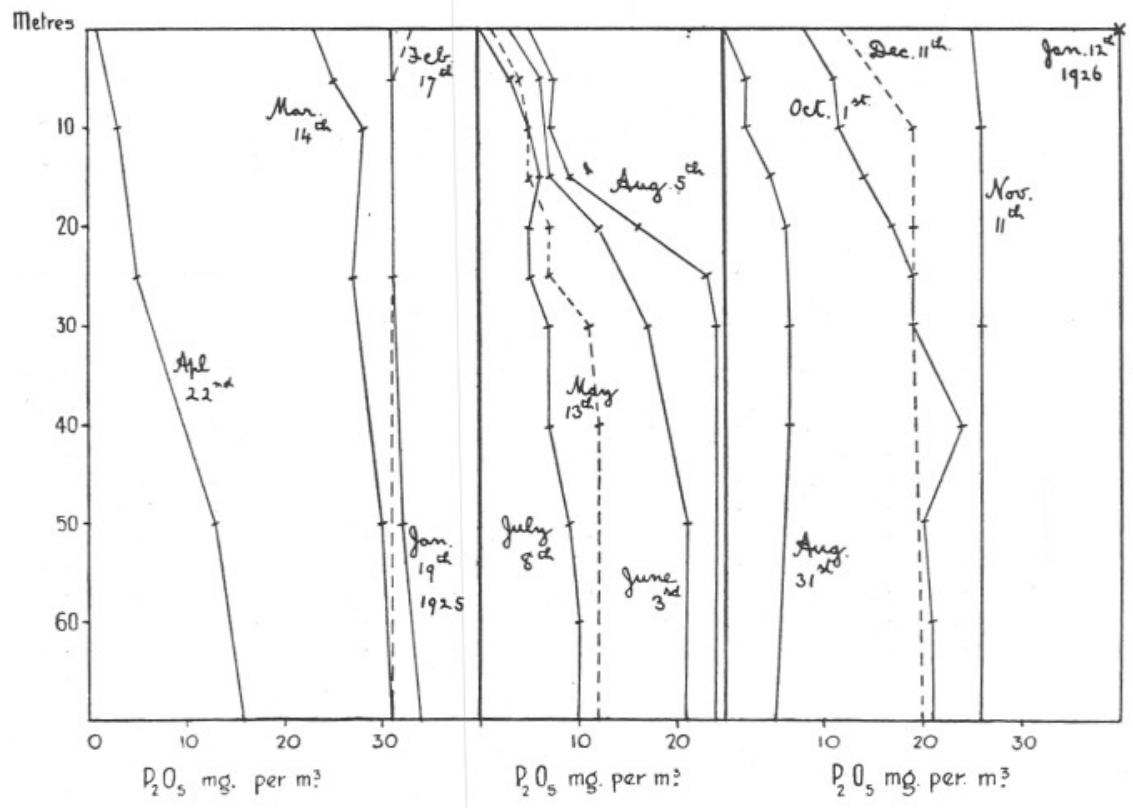

FIG. 3.-Variation of phosphate concentration with depth at Station El during 1925. For the sake of clearness the curves for the months have been plotted in three sections.

The years are, in broad outline, very similar, thus in each the mid-winter value is a maximum and the July a minimum at $7 \cdot 4,8.7$ and $6.9 \mathrm{mg}$. per $\mathrm{m}^{3}$, though the last value is exceeded in 1925 by the late August value, $5 \cdot 1 \mathrm{mg}$., the absolute minimum for the water column for the three years. Inspection of Fig. 4, however, shows clearly that striking differences exist. Thus in 1923, April, and to a greater degree May, witnessed a marked increase in the phytoplankton; there was further increase in July and scarcely any in September. In 1924 development had commenced in February, and the March increase slightly exceeded that of April, 1923 ; April, May and June show a progressive wane in the increase; thereafter down-grade changes predominate, save for a slight 
production at the end of September. The 1925 season was late at the outset, even March showing less development than February, 1924. The end of March and the first half of April witnessed, however, a remarkable outburst in the phytoplankton. Table 2 and Figs. 1 and 3 show that almost all phosphate in the well-illuminated regions has been used up, even at 25 metres only $5 \mathrm{mg}$. per $\mathrm{m}^{3}$ remained. As might be expected there was no further increase in May, and in June there was a marked regeneration. Thus it is seen that the vernal development of phytoplankton was a maximum in May, 1923, March, 1924, and April,

\section{TABLE 3.}

Phosphate Content of the Water Column, Surface to Bottom, 70 metres, at Station E1, with DIFFERENCEs Between the CONSECUTIVE OBSERVATIONS.

1924

1925.

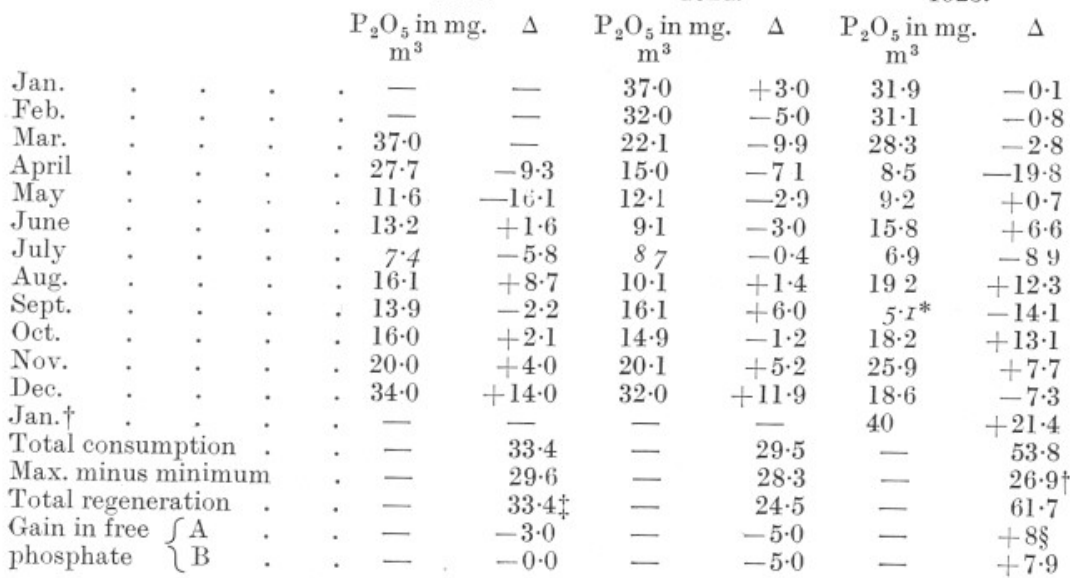

1925. Furthermore, late in June and early in July, 1925, the May and June regeneration, coupled with the vertical mixing (which is indicated by the rise in temperature in the bottom water recorded in Table 2), resulted in an outburst of phytoplankton similar to that of 1923, but greater. The remainder of July and early August were periods in which down-grade changes were well marked. But by late August vertical mixing, as again indicated by a rise in bottom temperature, afforded sufficient phosphate for a development of phytoplankton, which was

\footnotetext{
* Aug. 31st. Minimum values are in italics.

† Jan. 12th, 1926.

\$ Including value for Jan. 2, 1924 .

$\S$ Taking Dec., 1924, value as maximum.
} 
about three-quarters of the April outburst, almost as great as that of May, 1923 (the maximum for that year), and greater than in any single month of 1924. The lower part of Table 3 shows that the total consump-

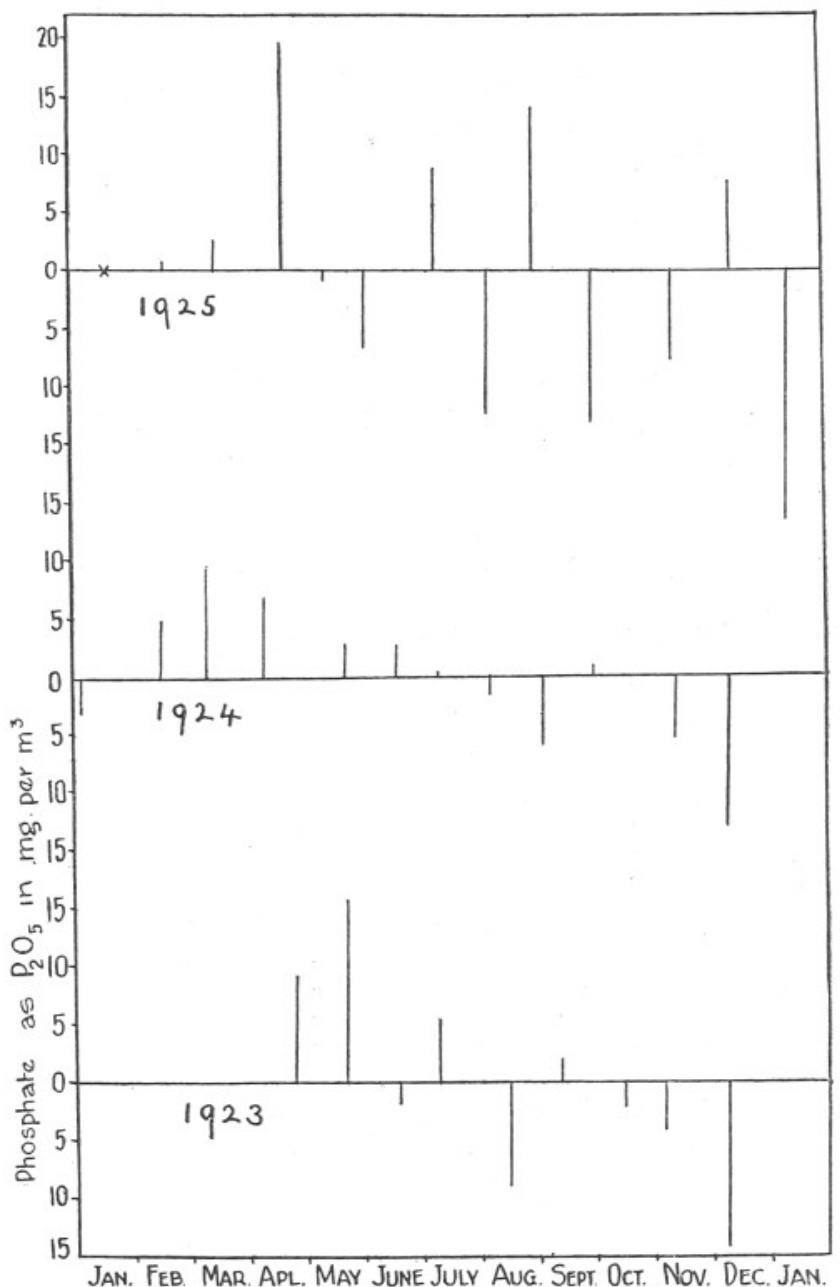

FIG. 4.-The production of phytoplankton may be deduced from the uprights above the zero line; in reality these lines show the difference in the phosphate content of the water between two successive observations. Increase in phosphate, being equivalent to destruction of phytoplankton is represented below the zero line.

tion proved for 1925 is considerably greater than for the other two years; but it must be borne in mind that this may only be apparent, due to the alternation of the processes of consumption and regeneration. It is none the less of biological importance. The results for "Gain in free 
phosphate" have been arrived at in two ways: (A) by subtracting the initial and final values, and (B) by subtracting the total consumption from the total regeneration. There is a difference of $3 \mathrm{mg}$. between the two for 1923 , for 1924 they agree, and for 1925 the difference is $0 \cdot 1 \mathrm{mg}$. The concordance must be considered satisfactory. The "A " values are obviously the most correct; it is to be noted that they indicate a slight retention of phosphate during 1923 and 1924, with an exactly equal total liberation by January, 1926. From the March, 1923, value and the latter, however, $3 \mathrm{mg}$. more phosphate is shown as free at the end of the three years than at the beginning. The January, 1923, results were not obtained. The foregoing figures make it quite clear that the phosphate cycle is essentially a closed one. There is no evidence that

\section{TABle 4.}

Dates when certain Phosphate Concentrations were reached at E1, Surface. Taking the 1923 dates as arbitrary standards THE ADVANCES OR RETARDATIONS OF 1924 AND 1925 ARE RECORDED.

\begin{tabular}{|c|c|c|c|c|c|}
\hline $\mathrm{P}_{2} \mathrm{O}_{5} \mathrm{mg}$. & 1) 23 & $19: 4$ & 1925 & $\begin{array}{c}\text { Ahead } \\
\text { in d s ys, } \\
1924\end{array}$ & $\begin{array}{c}\text { Ahead } \\
\text { in d :ys, } \\
1925\end{array}$ \\
\hline 30 & Mar. 30th & Feb. 18th & Feb. 25th & 41 & 33 \\
\hline 20 & April 28th & Feb. 28th & Mar. 20th & 59 & 39 \\
\hline 10 & May 10th & April 28th & April 6th & 12 & 34 \\
\hline $2 \cdot 5$ & May 21st & June 18th & April 18th & -28 & 33 \\
\hline 10 & Sept. 28th & $\begin{array}{l}\text { Sept. 2nd } \\
\text { Oct. 20th }\end{array}$ & Oct. 6th & $\begin{array}{l}+26 \\
-22\end{array}$ & - \\
\hline 20 & $\left.\begin{array}{l}\text { Oct. 11th } \\
\text { Nov. } 7 \text { th }\end{array}\right\}$ & Nov. 22nd & $\begin{array}{l}\text { Nov. 1st } \\
\text { Dec. 21st }\end{array}$ & $\begin{array}{r}-15 \\
-\end{array}$ & $\begin{array}{r}+6 \\
-44\end{array}$ \\
\hline 30 & Dec. 1st & Dec. 6th & Jan. 2nd & -5 & -32 \\
\hline
\end{tabular}

water movement affected this area materially during the period under consideration.

The differences between the corresponding seasons in the various years have already been discussed. A closer comparison may be made by a study of Tables 4 and 5, which show the dates at which certain phosphate concentrations were reached, as obtained by reading off from Figs. 1 and 2.

It is of interest to consider why the vernal outburst of phytoplankton, as indicated by phosphate consumption should have been earliest in 1924, latest in 1923, with 1925 occupying an intermediate position. In Fig. 5 are shown the mean monthly sunshine records for England, S.W. These 
are plotted for the 15th of each month, save for November and December, 1925, when the values taken were from the Plymouth records only, averaged over the periods between consecutive phosphate determinations. Inspection reveals the fact that the vernal outbursts occur in the three years in the same order as do the amounts of spring sunshine. Later on in the year the same exact correlation cannot be traced, for the phosphate is all used up near the surface. During the summer, as already mentioned, the important point is how extensively the phosphate from the depths is brought into the upper layers. In the autumn as the light becomes reduced and regeneration preponderates, the quantity of light will again determine how far the phytoplankton die out. There is, however, another factor, the smoothness of the sea, for in rough water much

\section{TABLE 5.}

Dates when certain Phosphate Concentrations were reached at E1, Bottom. Taking the 1923 dates as arbitrary standards THE ADVANCES OR RETARDATIONS OF 1924 AND 1925 ARE RECORDED.

\begin{tabular}{cccccc}
$\mathrm{P}_{2} \mathrm{O}_{5}$ mg. & \multicolumn{1}{c}{ 1923 } & 1924 & \multicolumn{1}{c}{1925} & 1924 & 1925 \\
30 & April 14th & Feb. 20th & Mar. 17th & 54 & 28 \\
20 & May 9th & Mar. 17th & April 11th & 53 & 28 \\
11 & July 9th & June 18th & July 6th & 21 & 3 \\
& & & Nune 1st & - & - \\
20 & Nov. 6th & Nov. 4th & \{ July 29th & - & - \\
& & & Dept. 29th (final) & 2 & 38 \\
30 & Dec. 1st & Dec. 4th & Dec. 28th & -3 & -27
\end{tabular}

of the light is scattered and reflected at the surface, and the quantity entering is correspondingly reduced. The year 1924 had no November outburst of phytoplankton (see Fig. 4), and Fig. 5 shows that its sunshine average was low. However, 1923 and 1925 were very similar in sunshine, yet only 1925 gives evidence of a remarkable development of diatoms as mentioned in the author's paper on silicate in sea-water. Fig. 4 is constructed from the average phosphate content of the whole water column, and shows no phytoplankton development in the autumn. Fig. 1, however, which concerns surface data only, does show a decided fall in phosphate in November, and so indicates plant growth, though regeneration of phosphate in the deeper water masks the result to some extent. But if the 46th to 49th weeks of each of the two years, 1923 and 1925, are considered, namely, approximately the periods between 
the observations (November 7th and December 10th and November 11th and December 11th respectively), it is seen that 1923 averaged $3 \cdot 1$ hours and 1925 only $3 \cdot 0$, so it is evident that the amount of sunshine alone will not explain the difference, nor will the total daylight, for the dates are almost identical. It may be noted that the vertical circulation must have been more pronounced in 1925 than in 1923 over the November

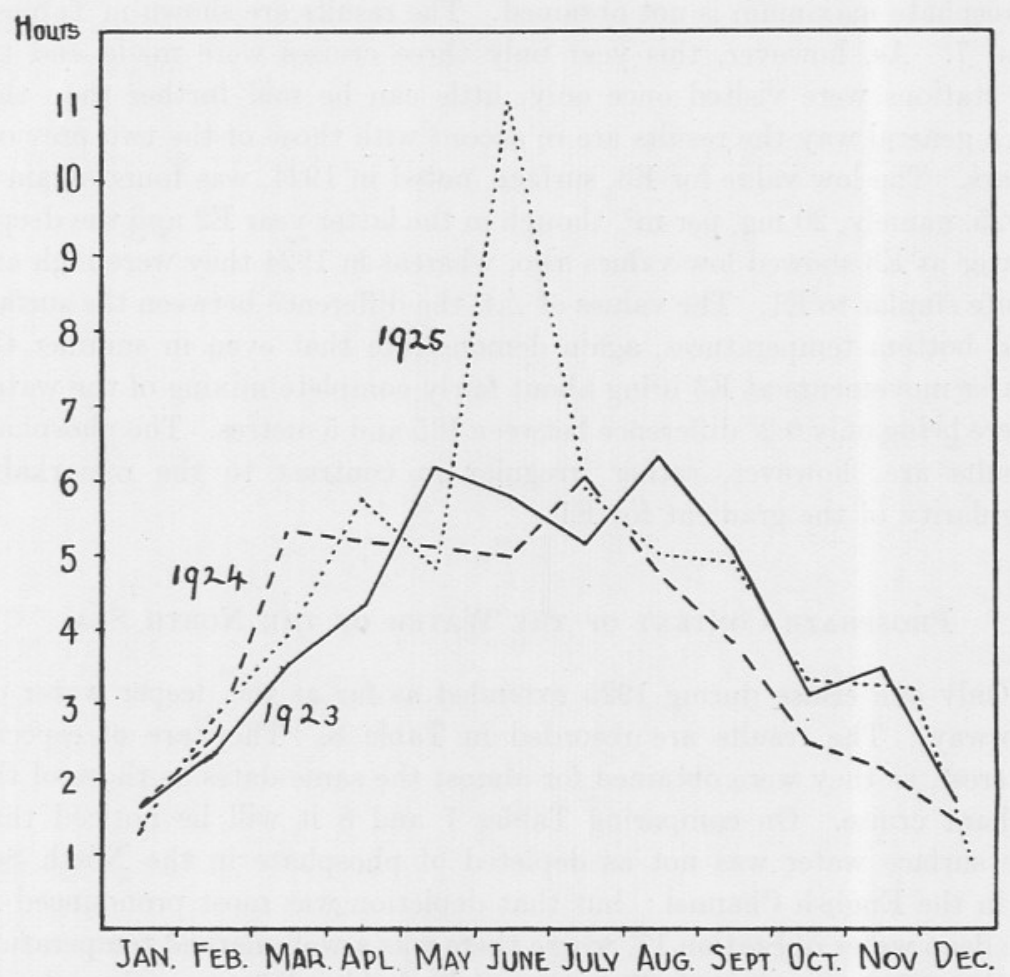

FIG. 5.-Mean monthly sunshine records for England, S.W. (including Wales), plotted for 15th of each month. For the sake of clearness the curves for the months have been plotted in three sections.

to December interval, for in November, 1923, the temperature difference between surface and $25 \mathrm{~m}$. was only $-0 \cdot 17^{\circ}$, and $25 \mathrm{~m}$. was the same as the bottom. It is possible that movement may have aided the mixing. In December the surface was $0 \cdot 30^{\circ}$ cooler than $25 \mathrm{~m}$., and the latter $0 \cdot 05^{\circ}$ cooler than the bottom. In 1925 , however, there was $-1^{\circ}$ difference between surface and $25 \mathrm{~m}$., and the bottom was $0.2^{\circ}$ warmer than the latter in November, whereas in December the reversed gradient from surface to bottom was only $0 \cdot 2^{\circ}$. 


\section{Seasonal Changes in the Phosphate Content of the Water of the} English Channel at the E and N Stations.

These stations, with the exception of E1 which has already been discussed, are only visited five times a year at the most, and the programme does not, unfortunately, include a visit at midwinter, so the phosphate maximum is not obtained. The results are shown in Tables 6 and 7. As, however, this year only three cruises were made and the $\mathrm{N}$ stations were visited once only, little can be said further than that in a general way the results are in accord with those of the two previous years. The low value for E3, surface, noted in 1924, was found again in 1925 , namely, $20 \mathrm{mg}$. per $\mathrm{m}^{3}$, though in the latter year E2 and the deeper water at E3 showed low values also, whereas in 1924 they were high and quite similar to $\mathrm{E} 1$. The values of $\Delta t$, the difference between the surface and bottom temperatures, again demonstrate that even in summer the water movements at E3 bring about fairly complete mixing of the water, there being only $0 \cdot 2^{\circ}$ difference between 105 and 5 metres. The phosphate results are, however, rather irregular in contrast to the remarkable regularity of the gradient for E1.

\section{Phosphate Content of the Water of the North Sea.}

Only one cruise during 1925 extended as far as the deeper water off Norway. The results are recorded in Table 8. They are of especial interest, as they were obtained for almost the same dates as those of the Ushant cruise. On comparing Tables 7 and 8 it will be noticed that the surface water was not as depleted of phosphate in the North Sea as in the English Channel ; but that depletion was most pronounced in the deep water of Station 17, where there was a well-marked temperature gradient between 0 and 20 metres. Probably differences in salinity account for the inverted gradient in temperature in the deeper water at this station. The richness of the bottom water in phosphate at all the stations is very remarkable, Stations $2-16$ average $44 \mathrm{mg}$. per $\mathrm{m}^{3}$, with, except No. 16, bottom at 60-80 metres. Station 17 has $49 \mathrm{mg}$. at $350 \mathrm{~m}$. Evidently the season is later in the North Sea than in the Channel, but this explains only the lesser depletion of the surface, not the richness of the bottom. In Part II, Tables 10 and 11, it may be seen that though one value for May, 1924, was up to $41 \mathrm{mg}$., none of the winter values, or the spring deep water values, were as high as those found in 1925 . A somewhat richer than usual algal plankton might, therefore, have been expected that year, or at least a more marked outburst at one time. 


\section{TABLe 6 .}

Phosphate as $\mathrm{P}_{2} \mathrm{O}_{5}$ In mg. Per $\mathrm{M}^{3}$ on cruise of February 17 th to 18Th, 1925. Surface and Bottom Temperatures are shown below. Analysed February 20Th.

$\begin{array}{cccccccc}\text { D p pth. } & \text { E 1. } & \text { Mid. } \ddagger & \text { E 2. } & \text { E 3*. } & \text { N 1. } & \text { Mid. } & \text { N 2. } \\ 0 & 33 & 19 & 16 & 20 & 20 & 21 & 26 \\ 5 & 31 & - & 19 & - & 26 & - & 26 \\ 15 & - & - & 21 & - & 25 & - & 31 \\ 50 & - & - & - & - & - & - & 31 \\ 70 & 31 & - & - & - & - & - & - \\ 90 & * & - & 21 & - & - & - & 30 \\ 100 & * & * & * & 22 & 24 & * & * \\ 0 & 9 \cdot 8^{\circ} & 10 \cdot 8^{\circ} & 10 \cdot 3^{\circ} & 10 \cdot 5^{\circ} & 10 \cdot 4^{\circ} & 10 \cdot 4^{\circ} & 10 \cdot 1^{\circ} \\ \text { Bottom } & 10 \cdot 0^{\circ} & - & 10 \cdot 7^{\circ} & 10 \cdot 8^{\circ} & 10 \cdot 6^{\circ} & - & 10 \cdot 3^{\circ}\end{array}$

\section{TABLE 7.}

Phosphate as $\mathrm{P}_{2} \mathrm{O}_{5}$ IN Mg. Per $\mathrm{M}^{3}$ and Temperature on Cruises of May 13th to 14th and July $8 \mathrm{Th}$ то 9тh, 1925.

\begin{tabular}{|c|c|c|c|c|c|c|c|c|c|c|c|c|}
\hline epth. & & 11. & & 2. & E & 33. & $\mathrm{E}$ & 1. & & 2. & & E3. \\
\hline & $t^{\circ}$ & $\mathrm{P}_{2} \mathrm{O}_{5}$. & $t^{\circ}$ & $\mathrm{P}_{2} \mathrm{O}_{5}$ & $t^{\circ}$. & $\mathrm{P}_{2} \mathrm{O}_{5}$. & $t^{\circ}$. & $\mathrm{P}_{2} \mathrm{O}_{5}$. & $t^{\circ}$ & $\mathrm{P}_{2} \mathrm{O}_{5}$. & $t^{\circ}$. & $\mathrm{P}_{2} \mathrm{O}_{5}$ \\
\hline 0 & $10 \cdot 7$ & 1 & $11 \cdot 8$ & 0 & $10 \cdot 8$ & 0 & $16 \cdot 0$ & 0 & $15 \cdot 6$ & 0 & $12 \cdot 6$ & \\
\hline 5 & & & & 10 & & & & & & & & \\
\hline 10 & & 5 & $10 \cdot 40$ & $1:$ & $10 \cdot 68$ & 2 & & & & & & \\
\hline & & 5 & - & 1 & - & 2 & & & $12 \cdot 35$ & 12 & & \\
\hline 2 & $9 \cdot 97$ & 7 & $10 \cdot 32$ & & $10 \cdot 46$ & & & & & & & \\
\hline & & & & $7 \cdot 5$ & - & & & & $12 \cdot 00$ & 12 & & \\
\hline & $9 \cdot 97$ & 11 & & & $10 \cdot 45$ & & $11 \cdot 80$ & & - & & $12 \cdot 02$ & \\
\hline 4 & - & 12 & & 1. & & & - & & - & 12 & & \\
\hline & $9 \cdot 97$ & & & & & 2 & & & $11 \cdot 90$ & & & \\
\hline 7 & $9 \cdot 96$ & 12 & $10 \cdot 32$ & 12 & $10 \cdot 45$ & & $11 \cdot 80$ & 10 & $11 \cdot 88$ & 13 & $11 \cdot 92$ & \\
\hline & & & & & & 23 & & & & & & \\
\hline & * & * & & 10 & - & & * & 4 & $11 \cdot 88$ & 10 & - & \\
\hline & ${ }^{*}$ & * & & & $10 \cdot 20$ & 16 & * & ${ }^{*}$ & * & & 1.90 & \\
\hline$\Delta t$ & $0 \cdot 7$ & - & $1 \cdot 5$ & - & $0 \cdot 6$ & - & $4 \cdot 2$ & - & $3 \cdot 7$ & - & $0 \cdot 7$ & \\
\hline
\end{tabular}

Intermediate stations on course to E3, surface :-

May, 18 miles on from El, $\mathrm{P}_{2} \mathrm{O}_{5}=0$. July, $\mathrm{P}_{2} \mathrm{O}_{5}=1$.

$$
\text { , } 26 \quad, \quad, \quad \mathrm{E} 2, \mathrm{P}_{2} \mathrm{O}_{5}=0 . \quad, \quad \mathrm{P}_{2} \mathrm{O}_{5}=0 \text {. }
$$

* Not as far as E 3, position $4 \mathrm{~S}^{\circ} 56^{\prime} \mathrm{N}, 4^{\circ} 54^{\prime} \mathrm{W}$.

‡ Midway between adjacent stations. 
Whether the source of the higher phosphate content of the North Sea in May, 1925, was regeneration during the winter or an influx of richer water cannot as yet be decided till the hydrographic results deduced from salinity changes become available; the phosphate content of the water in the Faroe-Iceland and Faroe-Shetland Channels in July, 1925, was, however, such as to afford no argument against the possibility of a movement of water rich in phosphate into the North Sea. These results are shown in Table 9. It may be added that reference to Part II, Table 12, makes it clear that in 1924 the Shetland results would have been definitely against such a view, for the values were from $8-25 \mathrm{mg}$. per $\mathrm{m}^{3}$, save for one high value, $79 \mathrm{mg}$. in warm water south of the Wyville Thomson ridge at $800 \mathrm{~m}$. As previously mentioned the August values recorded in that table are vitiated by phosphate from the glass. For some unex-

\section{Table 8.}

Phosphate in deep Water off Norway and in North Sea in general, May $14 \mathrm{th}$ to $16 \mathrm{Th}$, 1925. Analysed May 25th. Position : $57^{\circ} 57^{\prime} \mathrm{N}$., $6^{\circ} 45^{\prime} \mathrm{E}$. FOR STA. 17.

$\begin{array}{lllll}\text { Sta. } 17 & \text { Sta. } 16 & \text { Sta. } 12 \text { Sta. } 10 & \text { Sta. } 8 & \text { Sta. } 6 \\ \text { Sta. } 4 & \text { Sta. } 2\end{array}$ Depth $\mathrm{P}_{2} \mathrm{O}_{5} \mathrm{mg}$. $t^{\circ} . \mathrm{P}_{2} \mathrm{O}_{5}$. $t^{\circ} . \mathrm{P}_{2} \mathrm{O}_{5} \cdot \mathrm{P}_{2} \mathrm{O}_{5} \cdot \mathrm{P}_{2} \mathrm{O}_{5}$. to. $\mathrm{P}_{2} \mathrm{O}_{5} \cdot \mathrm{P}_{2} \mathrm{O}_{5} \cdot \mathrm{P}_{2} \mathrm{O}_{5} \cdot t^{\circ}$. in metres per $\mathrm{m}^{3}$.

$\begin{array}{rrrrrrrrrrrrr}0 & 6 & 9 \cdot 08 & 10 & 8 \cdot 94 & 13 & 13 & 11 & 8 \cdot 74 & 14 & 13 & 15 & 8 \cdot 34 \\ 20 & 10 & 5 \cdot 98 & - & 7 \cdot 60 & - & - & - & 8 \cdot 45 & - & - & - & 7 \cdot 45 \\ 40 & 31 & 5 \cdot 20 & - & 5 \cdot 57 & - & - & - & 6 \cdot 74 & - & - & - & 6 \cdot 34 \\ 60 & 35 & 5 \cdot 83 & 40 & 5 \cdot 98 & 37 & 43 & 49^{*} & 6 \cdot 30 & 48 & 44 \dagger & 45^{k} & 6 \cdot 33 \\ 100 & 40 & 6 \cdot 63 & - & 6 \cdot 95 & * & * & * & * & * & * & * & * \\ 150 & 41 & 7 \cdot 10 & - & 7 \cdot 04 & - & - & - & - & - & - & - & - \\ 200 & 41 & 6 \cdot 56 & - & 7 \cdot 04 & - & - & - & - & - & - & - & - \\ 250 & 44 & 6 \cdot 75 & - & 6 \cdot 88 & - & - & - & - & - & - & - & - \\ 300 & 46 & 6 \cdot 48 & - & 6 \cdot 79 & - & - & - & - & - & - & - & - \\ 350 & 49 & 6 \cdot 08 & * & * & - & - & - & - & - & - & - & -\end{array}$

plained reason the July, 1925, Shetland values are far higher than those of March to May, 1924. Such variations may afford the key to the periodic changes in the productiveness of the North Sea fishing grounds. The results recorded in Table 9 illustrate well the storage of phosphate in the deeper waters.

\section{Phosphate Content of the Water of the open Atlantic.}

In Table 10 are shown a few values for the open water south of Ireland and in the Bay of Biscay. The inshore water surface values are high in winter, and the May results show how the lines of equal phosphate content move upwards as the shore is approached. Thus at $60 \mathrm{~m}$. near

$$
\text { * Depth, } 70 \mathrm{~m} \text {. † Depth, } 80 \mathrm{~m} \text {. }
$$


TABLe 9 .

Phosphate Content and Temperature in (A) the Faroe-Iceland Channel, $4 / 7 / 25$, at $62^{\circ} 53^{\prime} \mathrm{N}$., $9^{\circ} 05^{\prime} \mathrm{W}$.; in (B) the Faroe-ShetLand Channel, 6/7/25, at $61^{\circ} 27^{\prime} \mathrm{N}$. AND $4^{\circ} 23^{\prime} \mathrm{W}$.; ALso (C) at $61^{\circ} 02^{\prime} \mathrm{N}$., $3^{\circ} 22^{\prime} \mathrm{W}$. Analysed 22 and $23 / 7 / 25$.

\begin{tabular}{|c|c|c|c|c|c|c|}
\hline \multirow[b]{2}{*}{ Depth. } & \multicolumn{2}{|c|}{ A. } & \multicolumn{2}{|c|}{ B. } & \\
\hline & $\mathrm{P}_{2} \mathrm{O}_{5}$ & $t^{\circ}$ & $\mathrm{P}_{2} \mathrm{O}_{5}$ & $t^{\circ}$ & $\mathrm{P}_{2} \mathrm{O}_{5}$ & $t^{\circ}$ \\
\hline 0 & $70^{*}$ & $10 \cdot 23$ & 30 & $10 \cdot 95$ & $23 \S$ & $12 \cdot 90$ \\
\hline 10 & 30 & $10 \cdot 20$ & 30 & $10 \cdot 12$ & 15 & $11 \cdot 89$ \\
\hline 20 & 30 & $9 \cdot 90$ & 27 & $9 \cdot 61$ & 21 & $10 \cdot 92$ \\
\hline 30 & 30 & $9 \cdot 43$ & 23 & $9 \cdot 38$ & - & $10 \cdot 42$ \\
\hline 40 & 41 & $8 \cdot 64$ & 43 & $8 \cdot 38$ & $33 \dagger$ & $10 \cdot 15$ \\
\hline 60 & 38 & $8 \cdot 32$ & 53 & $7 \cdot 83$ & - & $9 \cdot 66$ \\
\hline 80 & 53 & $8 \cdot 08$ & 70 & $7 \cdot 67$ & 40 & $9 \cdot 44$ \\
\hline 100 & $60 \dagger$ & $8 \cdot 03$ & 57 & $7 \cdot 52$ & 43 & $9 \cdot 30$ \\
\hline 200 & 57 & $7 \cdot 74$ & 57 & $6 \cdot 96$ & 一. & $8 \cdot 42$ \\
\hline 300 & 57 & $7 \cdot 51$ & - & $5 \cdot 33$ & 54 & $7 \cdot 30$ \\
\hline 400 & 57 & $2 \cdot 03$ & - & $2 \cdot 49$ & - & $6 \cdot 09$ \\
\hline 500 & 59 & $3 \cdot 38$ & 43 & 0.99 & 54 & $+2 \cdot 22$ \\
\hline 600 & $\star$ & $\star$ & -1 & $+0 \cdot 17$ & 57 & -0.48 \\
\hline 700 & $\star$ & $\star$ & -1 & $-0 \cdot 36$ & - & $-0 \cdot 60$ \\
\hline 800 & $\star$ & $\star$ & -1 & $-0 \cdot 47$ & 59 & $-0 \cdot 70$ \\
\hline 900 & $\star$ & $\star$ & $43 \ddagger$ & -0.50 & $\star$ & $\star$ \\
\hline 1000 & $\star$ & $\star$ & 58 & -0.56 & $\star$ & $\star$ \\
\hline
\end{tabular}

TABLE 10.

Phosphate and Temperature at various positions and Depths on the Atlantic slope.

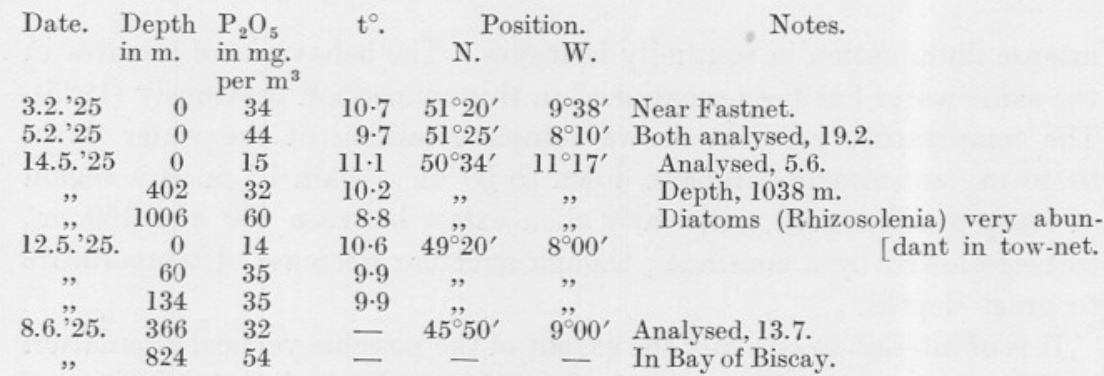

* A considerable amount of suspended matter in water sample.

$\dagger$ Result checked against fresh standard.

\pm Noted at time of analysis as obviously a much weaker tint than $1,009 \mathrm{~m}$. valus.

$\S$ Noted as definately stronger than $10 \mathrm{~m}$. value.

- Three bottles broken. 
the coast $35 \mathrm{mg}$. was found, and 32 further out at $402 \mathrm{~m}$. and the same at $366 \mathrm{~m}$. in the Bay. The bottom values for the deep water are almost identical in Tables 9 and 10, 58 and $60 \mathrm{mg}$. respectively at $1000 \mathrm{~m}$.

Table 11 contains similar results for the very deep water further south, between the latitudes of Lisbon and the Canary Isles. Again the accumulation of phosphate in the depths is very marked, but the most striking result is the complete removal of phosphate from the upper layers down to $50 \mathrm{~m}$., with as little as $5 \mathrm{mg}$. at $75 \mathrm{~m}$. This is due apparently to the fact that photosynthesis is active to greater depths owing to the more

\section{TABLE 11.}

Phosphate Content and Temperature at $37^{\circ} 44^{\prime} \mathrm{N}$. and $13^{\circ} 21^{\prime} \mathrm{W}$, on October 12, 1925, Save that at 3000 M., Taken on October 16 , at $29^{\circ} 59^{\prime} \mathrm{N} ., 15^{\circ} 03^{\prime} \mathrm{W}$. Analysed October 39 to November 2.

$\begin{array}{rcc}\mathrm{m} . & \begin{array}{c}\mathrm{P}_{2} \mathrm{O}_{5} \text { in } \mathrm{mg} . \\ \text { p } \mathrm{r} \mathrm{m}^{3} .\end{array} \\ 0 & 0 & \mathrm{t}^{\circ} \\ 40 & - & 21 \cdot 10 \\ 50 & 0 & 21 \cdot 00 \\ 75 & 5 & 20 \cdot 01 \\ 100 & 8 & 17 \cdot 31 \\ 150 & 10 & 15 \cdot 10 \\ 200 & 22 & 15 \cdot 06 \\ 300 & 44 & 13 \cdot 86 \\ 500 & 50 & 12 \cdot 25 \\ 1000 & 74 & 10 \cdot 94 \\ 2000 & 78 & 9 \cdot 55 \\ 3000 & 88 & 4 \cdot 81 \\ & & 3 \cdot 10\end{array}$

intense illumination in southerly latitudes. The behaviour of nitrates in the same water has been mentioned in this connection previously (1925). The temperature gradient shows complete mixing of the water down to $40 \mathrm{~m}$., and nearly complete down to $50 \mathrm{~m}$. Again $75 \mathrm{~m}$. is a region of steep gradient and uniformity then exists between 100 and $150 \mathrm{~m}$., to be followed by a continual, though irregular decrease of temperature to great depths.

It is of interest to consider the extent of the possible vertical circulation of the water at an open station such as this. Obviously irregularities of the bottom are without effect, and the factors concerned are, firstly, density changes due to cooling, and, secondly, wave motion. It is generally admitted that thermal conduction is negligible in water masses in com- 
parison with convection effects, so cooling due to the cold bottom water may be left out of account. Consequently the temperature of the lower portion of the isothermal water column cannot fall below that of the surface. The July isothermal lines show a temperature of about $22^{\circ}$ at this station, the corresponding January value being $12.5^{\circ}$. This may not be quite the minimum judging by experience further north, but it is probably not far from $12^{\circ}$. It seems legitimate, therefore, to conclude that vertical circulation due to cooling will be such that it extends downwards to the depth where $12^{\circ}$ is found, namely, at slightly over 300 say, 350 metres. Above this the temperature will be uniformly that of the surface, neglecting a slight lag. This is what is found in the English Channel in winter right down to the bottom, 70-80 m. Below $350 \mathrm{~m}$. we may expect the change to be negligible. It results that the phosphate enrichment of the surface water will be that produced by the mixing, together with that due to regeneration from the organisms which liberate phosphate in the first 350 metres, but the larger animals sink when they die and so carry down their phosphate to greater depths. Taking $46 \mathrm{mg}$. per $\mathrm{m}^{3}$ as the value for $350 \mathrm{~m}$. and averaging the values of the column up to the surface the result is $20 \mathrm{mg}$. per $\mathrm{m}^{3}$. This is, of course, a minor limit as regeneration which must take place cannot be calculated. As an upper limit we may hazard $46 \mathrm{mg}$.- for the depletion at the surface is due to removal of phosphate by algæ under the action of light. It seems, however, very unlikely that the major limit is even approached at this latitude, where illumination is never very greatly reduced. Indeed, the minor limit of $20 \mathrm{mg}$. neglects the fact that near the surface, even in winter, photosynthetic processes probably preponderate in these latitudes. According as we proceed northwards the surface cooling becomes greater and the deep water temperatures are also lower, so the vertical circulation will proceed to progressively greater depths. Conversely near the equator* the temperature changes throughout the year are small, so what vertical circulation there is must be due in the main to wave motion - which cannot be effective to any very great depthand not to density changes. Thus no considerable seasonal change in phosphate content is to be expected. Another important factor in increasing the yearly phosphate turnover in northerly latitudes is the great reduction in the light, which is, of course, the fundamental cause of the cycle wherever found. The further north we go the greater is the reduction in both sunlight and daylight, till the region of complete darkness is reached. In that it must be imagined that there is great destruction of plant life during the winter, so that the onset of sunlight in the spring finds the water rich in phosphate.

* There is, however, a region of upwelling on a vast scale near the equator, as cold bottom water replaces that blown polewards by the trade winds.

NEW SERIES.-VOL. XIV. No. 2. AUGUST, 1926.

$2 G$ 
Information about the phosphate cycle in the open ocean is provided by the data of Table 12, which shows how completely the southern waters are deprived of phosphate in summer, whereas even in December and in March the amount present at the surface is small. By a fortunate chance the samples on the northerly route were taken near the dates of the southerly in August. Even allowing for the fact that they were $8 \mathrm{~m}$. samples, not surface, it is clear that in them phosphate was far from being exhausted.

Table 13 records the results of analyses made of water from the Pacific, but owing to prolonged storage, from five months to a year, many of the

TABLE 12.

Phosphate Values and Temperatures in the Atlantic, Liverpool to Para, Surface Samples taken by s.s. Hildebrand. Also From Southampton to Quebec, From ENGINE ROOM INTAKE, 8 M. BELOW SURFACE BY C.P.R. STEAMER ; LATTER TAKEN 26-27/8/'25. Analysed 12/10/'25.

\begin{tabular}{|c|c|c|c|c|c|c|c|}
\hline Analyse & & Anal. 5.9. & 20 & Anal. 8.1 & 26 & Lat. I & Long. \\
\hline $\begin{array}{l}\mathrm{P}_{2} \mathrm{O}_{5} \\
\mathrm{mg} \cdot / \mathrm{m}^{3} \text {. }\end{array}$ & $t^{\circ}$ & $\begin{array}{l}\mathrm{P}_{2} \mathrm{O}_{5} \\
\mathrm{mg} \cdot / \mathrm{m}^{3} \text {. }\end{array}$ & $t^{\circ}$. & $\begin{array}{l}\mathrm{P}_{2} \mathrm{O}_{5} \\
\mathrm{mg} \cdot / \mathrm{m}^{3} \text {. }\end{array}$ & $t^{\circ}$ & N. & W. \\
\hline 6 & 26 & 0 & 28 & 34 & 28 & $0^{\circ} 20^{\prime} \mathrm{S}$. & $47^{\circ}$ \\
\hline - & 27 & - & & 20 & 28 & $1^{\circ}$ & $46^{\circ}$ \\
\hline - & 27 & - & & 6 & 27 & $2^{\circ}$ & $44^{\circ}$ \\
\hline 6 & 26 & 0 & 27 & 6 & 26 & $9^{\circ}$ & $39^{\circ}$ \\
\hline - & 25 & 2 & 24 & 7 & 25 & $19^{\circ}$ & $30^{\circ}$ \\
\hline - & 18 & 1 & 22 & 5 & 21 & $28^{\circ}$ & $21^{\circ}$ \\
\hline 9 & 14 & 2 & 20 & 7 & 17 & $38^{\circ}$ & $10^{\circ}$ \\
\hline 19 & 11 & 2 & 16 & 7 & 12 & $48^{\circ}$ & $7^{\circ}$ \\
\hline - & - & 23 & 13 & - & - & $53^{\circ}$ & $40^{\circ}$ \\
\hline - & - & 22 & 11 & - & - & $52^{\circ}$ & $50^{\circ}$ \\
\hline - & - & 25 & 10 & - & - & $52^{\circ}$ & $55^{\circ}$ \\
\hline
\end{tabular}

Approximate latitude.

Off Para.

Mouth of Orinoco.

Between Jamaica and Cuba.

N. Florida and Canary Is.

Azores and S. Portugal.

Ushant or Brest.

Galway or S. Labrador.

Mth. of Shannon or S. Labrador. Queenstown or Str. of BelleIsle.

results must be greatly vitiated by regeneration. On the whole, however, the water round the Galapagos and Marquesas Islands seems richer than that in the open ocean. The most interesting values are the first two, surface and $366 \mathrm{~m}$., which, with 47 and $167 \mathrm{mg}$. per $\mathrm{m}^{3}$ are exceptionally high and probably indicate an upwelling of deep water. The $366 \mathrm{~m}$. temperature is far lower than in the Atlantic, as shown in Table 11, where this value is not reached till below $1000 \mathrm{~m}$. It is of interest to recall J. Schmidt's (1925) comparison of the water on opposite sides of the Panama isthmus. He found surface water on both sides nearly saturated with oxygen, but whilst at $50 \mathrm{~m}$. the Atlantic is still nearly saturated the Pacific had only 0.25 as much as at the surface, and at $400-500 \mathrm{~m}$. the Pacific water was practically devoid of free oxygen, 
whereas the Atlantic had 40-50 per cent of that at the surface. Thus it looks as if the deeper water on the Pacific side was rich in decomposing organic matter which absorbed oxygen and liberated phosphate.

TABLe 13.

Phosphate Values and Temperatures in the Pacific, samples taken by the St. George. Not analysed till 13th to $18 \mathrm{TH}$ of JuLY, 1925.

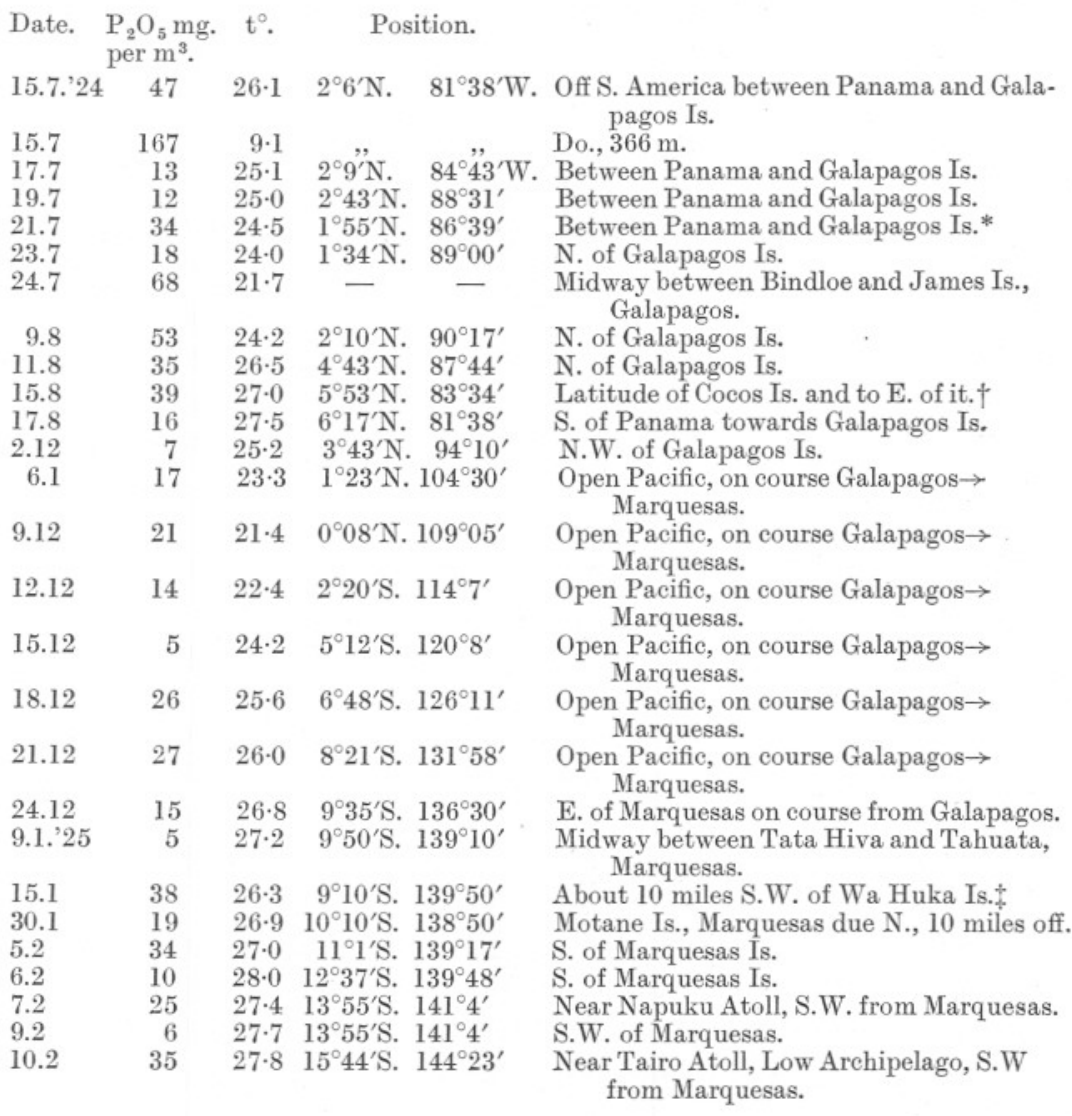

It may be added that the isothermal maps of the Atlantic show a cold area, under $21^{\circ}$ on the N.W. coast of Africa at about $25^{\circ}-32^{\circ} \mathrm{N}$. latitude, surrounded by a wide belt of warmer water, This would appear

\footnotetext{
* Current sets off continent here, E. to W.

$\dagger$ Current E. to W. in Pacific round Marquesas.

‡ Current sets towards continent, $W$ to E.
} 
to indicate a region of upwelling, which would probably be rich in phosphate at moderate depths and rich in plankton near the surface.

In conclusion the writer wishes to acknowledge his obligation, and to express his thanks to Mr. H. W. Harvey and the Captain and crew of the Salpa for assistance in obtaining water samples and temperatures, also to the Scotch and Irish Fishery Departments for samples obtained from Aberdeen and off the Irish coast, to the Air Ministry for the samples obtained through the courtesy of the officers of the s.s. Hildebrand, to Dr. C. Crossley for the Pacific samples, to Dr. L. T. Hogben for those on the Canadian route, also to Mr. C. F. Hickling for samples off the Irish coast in winter.

\section{SUMMARY.}

1. A comparison of the years 1923, 1924 and 1925 as regards the phosphate content of the water at Station E1 in the English Channel has shown that the vernal diminution was earliest in the year 1924, and latest in 1923, the extreme difference being approximately two months. These differences stand in direct relation to the spring sunshine, that of 1924 for the daily average of the 9 th to 12 th weeks inclusive being $2 \cdot 3$ hours in excess of the normal, 1923 being $0 \cdot 1 \mathrm{hr}$. in deficit and 1925 being $0 \cdot 6 \mathrm{hr}$. in excess. Since the phosphate diminution is proportional to the increase in phytoplankton the year 1924 must have been exceptionally early in this respect.

2. The year 1925 was in general similar to the other two in having a summer phosphate minimum and a winter maximum; but it was noticeable for marked periods of regeneration of phosphate, followed by utilization, within the main cycle.

3. The maximum value at $\mathrm{E} 1$ was $40 \mathrm{mg}$. per $\mathrm{m}^{3}$ of phosphate as $\mathrm{P}_{2} \mathrm{O}_{5}$, the minimum 5.1 mg. for the whole water column, 0-70 metres.

4. Much additional evidence has been found to show that the deep water of the ocean is a reservoir of phosphate, containing $50-80 \mathrm{mg}$. per $\mathrm{m}^{3}$, or more.

5. The water of the North Sea was markedly richer in phosphate in the spring of 1925 than in that of 1924 , as was also the water around the Faroe-Shetland Channel in July, 1925, as compared with the previous July. A causal connection may be sought.

6. In tropical waters the intense light normally results in the utilization of all phosphate down to at least 50 metres, and the winter cooling never suffices to effect mixing with the deeper water. At about $38^{\circ} \mathrm{N}$. latitude the water may be expected to be isothermal in winter to a depth of 350-400 metres, and further north the isothermal column has its base deeper down; accordingly the seasonal phosphate cycle must become more pronounced. 


\section{REFERENCES.}

Atkins, W. R. G. 1923. The phosphate content of fresh and salt waters in its relationship to the growth of the algal plankton. J. Marine Biol. Assoc., 13, No. 1, 119-150.

Atkrns, W. R. G. 1925. Seasonal changes in the phosphate content of sea-water in relation to the growth of the algal plankton during 1923 and 1924. Loc. cit., 13, No. 3, 700-720.

Atkins, W. R. G. 1926. Seasonal changes in the silica content of natural waters in relation to the phytoplankton. Loc. cit. 14, No. 1, 89-99.

Atkins, W. R. G., and Harvey, H. W. 1925. The variation with depth of certain salts utilized in plant growth in the sea. Nature, 116, 784 .

Matthews, D. J. 1916. On the amount of phosphoric acid in the sea-water off Plymouth Sound. J. Marine Biol. Assoc., 11, 122130. Also Pt. II, loc cit., 1917, 251 -257.

Schmidt, J. 1925. Contents of oxygen in the ocean on both sides of Panama. Science, 61, 592. 
